\title{
Tentative Identification of 2-Imidazoline as a Transformation Product of Ethylenebisdithiocarbamate Fungicides
}

\author{
J. W. Vonk and A. Kaars Sijpesteiun \\ Organisch Chemisch Instituut TNO, Utrech, The Netherlands \\ Received December 31, 1970; accepted March 8, 1971
}

\begin{abstract}
2-Imidazoline has been identified tentatively as a minor conversion product of ethylenethiourea in seedlings of cucumber and wheat. As ethylenethiourea is known to be present in plants after root treatment with ethylenebisdithiocarbamate fungicides, 2 -imidazoline is assumed to be a terminal residue of these fungicides as well.
\end{abstract}

\section{INTRODUCTION}

Vonk and Kaars Sijpesteijn (1) reported the ready uptake by plants of ethylenethiourea (I), a decomposition product of ethylenebisdithiocarbamate fungicides (nabam, zineb, maneb). After uptake of ethylenethiourea an unknown minor conversion product was detected. This conversion product has now tentatively been identified as 2-imidazoline (II) by comparing its chromatographic and electrophoretic behaviour with a synthetic sample.<smiles>S=C1NCCN1</smiles><smiles>C1=NCCN1</smiles>

\section{MATERIALS AND METHODS}

Cucumber and wheat seedlings were placed with their roots in a solution or suspension of ethylenethiourea (300-1000 ppm, 5 days), nabam (100 ppm, 2 days), zineb (1000 ppm, 2 days), or maneb (1000 ppm, 2 days).
Extracts were obtained by adding an equal volume of ethanol to sap pressed from the plants. The precipitate was discarded. The preparation of the nitroprusside-ferricyanide spraying reagent and further details have been published elsewhere (1).

The concentration of 2-imidazoline and ethylenethiourea in plant extracts was estimated by comparison of the size of the spots after chromatography with that of a range of kuown amounts of 2-imidazoline picrale and ethylenethiourea, respectively. Paper electrophoresis (apparatus of LKB, type 3290 B) was carried out with Whatman $3 \mathrm{MM}$ paper at $300 \mathrm{~V}$.

2-Imidazoline was synthesized according to Jentzsch and Seefelder (2). A glassy mass was obtained, which could be purified as the picrate, $\mathrm{mp} 164^{\circ}$ [lit.(3) $164-165^{\circ}$ ]. $\mathrm{nmr}$ (100 $\mathrm{MHz}$ in acetone- $\left.d_{6}\right): \delta 3.75$ (broad, $1 \mathrm{H}$, $-\mathrm{NH}) ; \delta 4.14\left(\mathrm{~s}, 4 \mathrm{H},-\mathrm{CH}_{2}-\mathrm{CH}_{2}-\right) ; \delta$ $8.52(\mathrm{~s}, 1 \mathrm{H},=\mathrm{CH}-) ; \delta 8.67(\mathrm{~s}, 2 \mathrm{H}$, aromatic protons); $\delta 9.9$ (broad, $1 \mathrm{H},-\mathrm{OH})$.

\section{RESULTS AND DISCUSSION}

Extracts of cucumber and wheat seedlings treated with ethylenethiourea were co-chromatographed with a synthetic sample of 2-imidazoline picrate on cellulose thin layers in several solvent systems. When these chromatograms were sprayed with nitro- 
TABLE 1

Chromatographic properties of compounds observed in extracts of ethylenethiourea-lreated plants in comparison with properties of synthetic 2-imidazoline

\begin{tabular}{lcccccc}
\hline & \multicolumn{3}{c}{$R_{F}$ value in solvent system } & & \multicolumn{2}{c}{$\begin{array}{c}\text { Colour with } \\
\text { nitroprusside- } \\
\text { ferricyanide }\end{array}$} \\
\cline { 5 - 7 } & $\mathrm{A}$ & $\mathrm{B}$ & $\mathrm{C}$ & $\mathrm{D}$ & \\
\hline $\begin{array}{l}\text { Plant extracts } \\
\quad \text { Ethylenethiourea }\end{array}$ & $\mathbf{0 . 6 8}$ & 0.60 & 0.61 & 0.80 & Blue \\
$\quad$ Unknown & 0.38 & 0.25 & 0.30 & $0.70^{b}$ & Blue-violet \\
$\quad$ 2-Imidazoline (synthetic) & 0.38 & 0.25 & 0.30 & $0.70^{b}$ & Blue-violet \\
\hline
\end{tabular}

a Solvent systems: A: Butanol-acetic acid-water $(4: 1: 1)$; B: Butanol-ethanol-water $(120: 33: 57)$; C: Propanol-water (85:15); D: Propanol-6 $\mathrm{N} \mathrm{NH}_{4} \mathrm{OH}(4: 1)$.

${ }^{b}$ Partial decomposition

prusside-ferricyanide reagent, spots appeared with a characteristic colour (Table 1). Plant extracts revealed two spots, viz., unchanged ethylenethiourea and the unknown compound; synthetic 2-imidazoline picrate separated into 2-imidazoline and picric acid, as indicated by a yellow spot. The unknown spot from plant extracts appeared to be chromatographically identical with 2 -imidazoline.

Paper electrophoresis in $1 \mathrm{~N}$ acetic acid showed the identical behaviour of the unknown compound and 2-imidazoline. Both compounds moved with the same velocity to the cathode $(4.7 \mathrm{~cm}$ in $1.5 \mathrm{hr})$.

The unknown compound and synthetic 2-imidazoline also gave the same characteristic colour reaction with nitroprusside-ferricyanide spraying reagent. Initially a blue-violet colour appeared, which turned to purple after several hours.

These results suggest that part of the ethylenethiourca is converted into 2-imidazoline by plant tissue. The concentration of 2-imidazoline in sap of cucumber seedlings, placed for 5 days with the roots in $500 \mathrm{ppm}$ ethylenethiourea, was estimated to be 10-20 ppm. The concentration of ethylencthiourea in the sap was $700 \mathrm{ppm}$ at this moment. The fact that only a very small part of ethylene. thiourea is converted into 2-imidazoline is in good agreement with the previously estab- lished stability of ethylenethiourea in plants (1).

In cucumber plants treated via the roots with nabam, zineb, or maneb ethylenethiourea, but no 2-imidazoline, was detected. Obviously, the amount of ethylenethiourea and thus of 2-imidazoline in the plant is so low after treatment with bisdithiocarbamates, that 2 -imidazoline escapes detection.

2-Imidazoline and ethylenethiourea have been mentioned as intermediate degradation products of mancozed applied to plants (3). No further detajls were given. Our findings suggest that also in this case 2-imidazoline is formed with ethylenethiourea as an intermediate. Possibly more ethylenethiourea and thus more 2-imidazoline is formed from mancozeb than from other bisdithiocarbamates or more sensitive detection methods were used.

The mechanism of conversion of ethylenethiourea into 2-imidazoline is still obscure. $\Lambda$ s reported carlier the compound is also formed in plant sap to which ethylenethiourea had been added, and even in sap denatured by addition of alcohol or by boiling, but not in water or phosphate buffer. It thus scems that certain plant constitucnts catalyze this nonenzymatic reaction.

The removal of sulfur from cyclic thiourea derivatives by a living organism has not been reported before, although substitution of 
sulfur by oxygen has been observed in several cases, e.g., thiouracil, thiobarbiturates (cf. 4).

\section{ACKNOWLEDGMENT}

Thanks are due to Dr. J. C. Overeem and Mr. H. Mak for synthesizing 2-imidazoline, and to Mrs. J. M. Jongerius for able assistance.

\section{REFERENCES}

1. J. W. Vonk, and A. Kaars Sijpesteijn, Studies on the fate in plants of ethylenebisdithio- carbamate fungicides and their decomposition products, Ann. Appl. Biol. 65, 489 (1970).

2. W. Jentzsch and M. Seefelder, Ueber $N, N^{\prime}$ disubstituierte Formamidine, Chem. Ber. 98, 1342 (1965).

3. 1967 Evaluations of some pesticide residues in food, FAO/WHO monograph, p. 178, Rome 1968 (unpublished data submitted by Rohm and Haas).

4. R. T. Williams, "Detoxication Mechanisms," Chapman and Hall, London (1959). 